https://doi.org/10.47669/CEERS-2-2019

\title{
Europe's Last Dictatorship: The State of Civil Liberties in Belarus
}

\section{Aram TERZYAN*}

This paper explores the state of civil liberties and human rights in Belarus, with a focus on the malpractices that gained Lukashenko's country the reputation of Europe's "last dictatorship."

The rule of Alexander Lukashenko in Belarus has created one of the most resilient authoritarian regimes in post-communist Europe. Situated in the European Union - Russia shared neighborhood, Belarus has been characterized by 'Soviet nostalgia' rather than European aspirations. Politically, Belarus shows more similarities with the republics of postSoviet Central Asia than with its neighbors in Europe. Since the collapse of the Soviet Union Belarus has gone from being a new and fragile democracy to a pariah state, largely regarded as "the last dictatorship in Europe" (Rudling, 2008).

Authoritarianism in Belarus appears to last longer than expected, with the country becoming a "non-democratic hole in the heart of Europe" (Frear, 2019, p. 1). As a result, Belarus remains an authoritarian police state with falsified elections and restricted civil liberties (Freedom House, 2019). The freedom of assembly and expression have been severely limited, with

\footnotetext{
* Aram Terzyan, PhD, is visiting senior lecturer at UNESCO Chair of Human Rights, Democracy and European Studies, Brusov State University of Social Sciences and Languages. Email: aramterzyan@gmail.com.
} 
the government controlling the media narrative on politically sensitive issues. The opposition has been weak and fragmented, with opposition actors maintained in a 'ghetto', tightly managed by the ruling authorities. Moreover, it has not been uncommon for opposition activists to get harassed, threatened and arrested (Freedom House, 2019).

Not surprisingly, Belarus has found itself the target of consistent criticism on the part of Europe's main international organizations and the United States for failing to meet what most European nations recognize as international democratic standards. The administration of President Lukashenko, who has been in power since 1994, finds itself in a state of confrontation with 'the West', primarily due to its non-espousal of these standards - at least as perceived by the country's critics (Rontoyanni and Korosteleva, 2005).

Belarus is frequently regarded as the 'European' Police State, given the authorities' heavy reliance on police forces in terms of sustaining their authoritarian rule and suppressing the opposition (Radio Liberty, 2010). The Belarusian authorities at all levels operate with impunity, while failing to take steps to prosecute or punish officials in the Government or security forces who commit human rights abuses. Former Chief Justice of Belarus's Constitutional Court, Valery Tsikhinia once called the situation in the country "legalized lawlessness" - government institutions and their leaders carry out laws in an arbitrary manner, while citizens are bereft of any understandable rules of the game (Radio Liberty, 2010).

In effect, Belarusian police often threaten rather than protect the public. Law enforcement agencies have broad powers to employ physical force against suspects, who have little opportunity for recourse if they are 
Europe's Last Dictatorship: The State of Civil Liberties in Belarus

abused. Human rights groups continue to document instances of beatings, torture, and pressure during detention (Freedom House, 2019).

Major human rights issues in Belarus range from arbitrary arrests and detentions to widespread discrimination and violence against minority groups.

While the Council of Europe qualifies the death penalty as cruel, inhumane, and degrading, Belarus remains the only European country to exercise death penalty as a punishment (Corlățean, 2019).

The Belarusian Constitution stipulates that the death penalty can be applied for particularly grave crimes (Viasna, 2017). The long list of those stipulated in the Criminal Code of Belarus include: "unleashing or conducting an aggressive war" (Article 122 part 2 of the Criminal Code of Belarus), "murder of a representative of a foreign state or international organization with the intention to provoke international tension or war" (Art. 124 part 2), “international terrorism” (Art. 126), "genocide” (Art. 127), “crimes against humanity" (Art. 128), "premeditated, aggravated murder" (Art. 139 part 2), “terrorism” (Art. 289 part 3), "terrorist acts” (Art. 359), "treason accompanied by murder" (Art. 356 part 2), "conspiracy to seize power" (Art. 357 part 3), "sabotage” (Art. 360 part 2), "murder of a police officer" (Art. 362), "use of weapons of mass destruction" (Art 134), and "murder of a person in violation of the laws and customs of war" (Art. 135 part 3) (OSCE, 2009).

According to human rights organizations, more than 400 people have been sentenced to death in Belarus since it gained independence following the collapse of the Soviet Union in 1991 (Radio Liberty, 2019). 
In Belarus, there are two main practices accompanying the application of death penalty, that are against the international law. First, the authorities carry out executions in secret and refuse to release the bodies of executed prisoners to their families. Relatives may be informed of the execution by letter weeks or months after the event. Article 175 of the Criminal Executive Code of the Republic of Belarus also allows for the government not to communicate the place of burial of those executed to their relatives (Death Penalty Database, 2014). Second, in the light of massive violations of fair trial standards, including the practices of torture against pretrial detainees, it is reasonable to question the fairness of death sentences (Parliamentary Assembly, 2019).

According to the FIDH-HRC "Viasna" report, throughout investigation and trial, self-incrimination is used by the prosecution as the main evidence of guilt, whilst the right to an effective legal defense is systematically violated. Death sentences may be appealed to the Supreme Court. However, it rarely commutes death sentences and can even hand down harsher verdicts, as was the case for Siarhei Khmialeuski in 2015. Death sentences issued by the Supreme Court as a first instance court are not at all subject to appeal, in violation of international norms (FIDH HRC Viasna, 2016).

Many international organizations, including the European External Action Service have repeatedly called on Belarus to abolish capital punishment (Radio Liberty, 2019).

Minority rights in Belarus remain poorly protected with the ethnic or sexual minority groups facing wide and varied forms of discrimination. As stated in a report submitted to the UN Committee on the Elimination of All Forms of Racial Discrimination, "the Roma in Belarus are subject to 
Europe's Last Dictatorship: The State of Civil Liberties in Belarus

discrimination, particularly in employment, resulting in exclusion, extreme poverty, criminalization of the country's Roma population" (Viasna, 2017).

Meanwhile, the government "not only fails to take measures to improve the situation of the Roma population, but also subjects Roma people to repressions for the very fact of their miserable situation" (Viasna, 2017).

As stated in the report of Anaïs Marin, UN Special Rapporteur on human rights in Belarus, there have been several patterns of racial discrimination against the Roma Minority. It refers to racial profiling by the police, demonstrated through "harassment of Roma children, men and women, including repeated compulsory fingerprinting and arbitrary detention". Moreover, the Roma people are struggling to obtain identity documents amid huge bureaucratic obstacles on the path to citizenship (UN General Assembly, 2019). Notably, the involvement of the civil society representatives in providing access to education for the Roma community is much higher than that of the government (Zaçellari et al., 2018).

A group of non-governmental organizations including the Viasna Human Rights Centre, have repeatedly urged the Belarusian authorities to immediately put an end to all violence and persecution against the Roma community and to launch an independent and impartial investigation into the human rights abuses that took place in Mogilev, where 300 people were arbitrarily arrested, including 100 detained in raids which specifically targeted this minority ethnic group (International Federation for Human Rights, 2019). 
In terms of minority rights, it is necessary to note that LGBT community is one of the most discriminated and vulnerable groups in Belarus amid huge homophobia permeating all segments of the Belarusian society. President Lukashenko went so far as to contend, that it is "better to be a dictator than gay" (Spiegel, 2012).

There are many loopholes in the existing legal framework, that prevent the minorities from exercising their freedoms and rights, including those of expression, peaceful assembly, and association. Worries remain about the prevailing impunity for violating LGBT rights. It has not been uncommon for LGBT people to get rejected and turned away when seeking protection from law enforcement authorities (Eurasian Coalition on Male Health, 2017).

Along with minority groups, migrants and asylum seekers have been among the most disadvantaged groups in Belarus. The 1951 Convention pertaining to the Status of Refugees and its 1967 Protocol was adopted by the Belarussian government in 2001. In June 2008, the Republic of Belarus adopted the law On Granting Refugee Status, Complementary and Temporary Protection to Foreign Citizens and Stateless Persons, which defines a single mechanism for the consideration of the status of a refugee and reaffirms the non-refoulement principle. Supplementary laws were adopted to ensure the protection of the human rights of the refugees (UNHCR, 2014). Nevertheless, despite the solid legal framework, there is a series of shortcomings in this realm. According to the Amnesty International, Belarussian authorities violate the non-refoulement principle, coercively sending asylum-seekers to their home countries despite ensuing threats and risks (Amnesty International, 2019). In May 2019, the Belarusian law enforcement authorities arrested Russian blogger 
Europe's Last Dictatorship: The State of Civil Liberties in Belarus

and human rights defender Ismail Nalgiev and deported him to Russia, despite the likelihood of subjecting him to harm and mistreatment. Nalgiev was one of the activists protesting the land-swap deal between Ingushetia and Chechnya. The protests were forcibly dispersed with the organizers charged with crimes under Article 318(2) and Article 212(3) of the Criminal Code of the Russian Federation (Mhainín, 2019).

Overall, a question may arise as to if there have been significant ups and downs in terms of human rights and political freedoms protection in Belarus.

To answer this question, I have analyzed their annual Freedom House scores from 2008 to 2019, representing the levels of civil liberties and political rights in Belarus on a scale from 1 (most free) to 7 (least free).

\section{Chart 1: Freedom House Scores of Civil liberties and political freedoms in Belarus from 2008 to 2019}

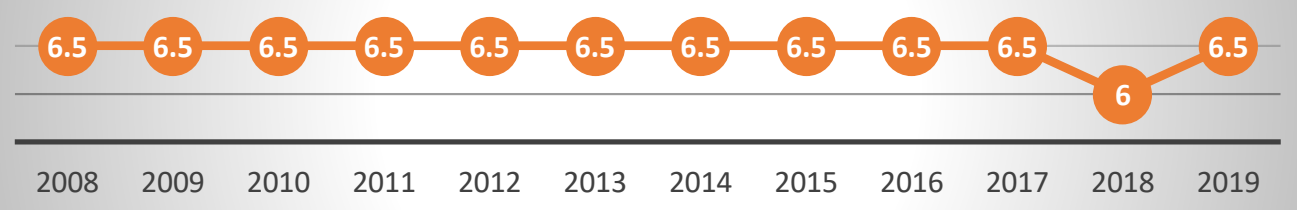

Source: Freedom House

Clearly, there have been no major shifts or considerable change over the past decade, while Lukashenko's authoritarian rule has remained intact.

Russian authoritarian support is a good part of the reason why Lukashenko's regime is so durable and resilient. Under the Lukashenko's regime, Belarus has become linked with Russia through a multitude of 
bilateral treaties and agreements covering virtually all areas of inter-state action. As a result, Russia's relationship with Belarus is closer than that of any other former USSR country. Ambrosio (2006), notes that the situation in Belarus is such that the external factors that have proved to promote democratization have been weakened or undermined by its relationship with Russia in general, and by the proposed Russia-Belarus union in particular (Ambrosio, 2006). Russian leaders, including Putin, have consistently legitimized Lukashenko's rule both diplomatically and politically, not least through defending Belarus's unfair and unfree elections. In the economic realm, Russia-Belarus trade and Russian subsidies shield Belarus from any possible trade sanctions from Western Europe, thus sustaining the regime's unreformed economic system (Ambrosio, 2006). In effect. of all Eastern Partnership countries, Belarus is most vulnerable to the Russian influence, with the two countries forming a union state being members of the same defense and economic communities. While the conventional wisdom suggests that faced with an imminent revolutionary threat, Russia consistently strives to fulfill its 'preventive counter-revolution' agenda in its neighborhood and beyond, the 2018 Velvet Revolution in Armenia seems to defy the Russian 'counterrevolution' policy.

Meanwhile, successful, mass-based opposition to a ruling elite tends to serve as an example to discontented elements in other countries. A question arises as to whether Alexander Lukashenko's authoritarian regime in Belarus is resilient enough to shield itself from the diffusion effects of the 2018 "Velvet Revolution" in Armenia. Whether or not the Belarusian 
Europe's Last Dictatorship: The State of Civil Liberties in Belarus

civil society will be able to challenge the statis quo in the wake of 2020 presidential elections in Belarus is yet to be seen.

\section{References}

Ambrosio, T. (2006). The Political Success of Russia-Belarus Relations: Insulating Minsk from a Color Revolution. Demokratizatsiya, 14(3), pp. 407-434.

Amnesty International (2019). Everything you Need to Know about Human Rights in Belarus. Retrieved November 30, 2019, from https://www.amnesty.org/en/countries/europe-and-centralasia/belarus/report-belarus/ .

Corlăţean T. (2019). Abolishment of the Death Penalty in Europe. Study Case: Belarus. Jurnalul Libertății de Conștiințăa, 7(2), pp. 405-16.

Death Penalty Database (2014): Belarus. Retrieved June 15, 2019 from https://dpw.pointjupiter.co/country-searchpost.cfm?country=Belarus.

Eurasian Coalition on Male Health. (2017). Legislative Analysis Related to LGBT Rights and HIV in Belarus. Retrieved September 20, 2019, from https://ecom.ngo/wpcontent/uploads/2018/03/BELARUS_ENG.compressed.pdf.

FIDH - HRC Viasna. (2016). Death Penalty in Belarus: Murder on (Un)lawful grounds. Retrieved October 29, 2019 from https://tbinternet.ohchr.org/Treaties/CAT/Shared\%20Documents/BLR/IN T_CAT_CSS_BLR_30786_E.pdf .

Frear, M. (2019). Belarus under Lukashenka: Adaptive Authoritarianism. Routledge.

Freedom House (2019). Belarus. Retrieved November 29, 2019 from https://freedomhouse.org/country/belarus/freedom-world/2019.

International Federation for Human Rights. (2019). Belarus: Mass Roundups of Roma People Must Be Investigated. Retrieved November 29, 2019, from https://www.fidh.org/en/region/europe-central- 
asia/belarus/belarus-mass-roundups-of-roma-people-must-beinvestigated.

Mhainín, J. (2019). Blogger and Human Rights Defender Ismail Nalgiev Extra-judicially Deported from Belarus. Retrieved December 10, 2019, from https://www.indexoncensorship.org/2019/05/blogger-andhuman-rights-defender-ismail-nalgiev-extra-judicially-deported-frombelarus/ .

OSCE (2009). The Death Penalty in the OSCE Area. Retrieved November 29 , 2019 ,

from https://www.osce.org/files/f/documents/4/0/33566.pdf.

Parliamentary Assembly (2019). Abolition of the Death Penalty in Council of Europe Member and Observer States. Retrieved October 29, 2019

from http://www.assembly.coe.int/LifeRay/JUR/Pdf/DocsAndDecs/2019/ASJUR-2019-50-EN.pdf .

Radio Liberty (2010). 'European' Police State, https://www.rferl.org/a/belarus_police_control_everything_/2258231.html.

Radio Liberty (2019). Belarusian Supreme Court Upholds Death Sentence in Double-Murder Case Retrieved June 18, 2019 from https://www.rferl.org/a/belarusian-supreme-court-upholds-deathsentence-in-double-murder-case/29940461.html .

Rontoyanni, C. and Korosteleva, E. (2005). Belarus: An Authoritarian Exception from the Model of Post-Communist Democratic Transition? In Socializing Democratic Norms (pp. 209-231). Palgrave Macmillan, London.

Rudling, P. A. (2008). Belarus in the Lukashenka era: National identity and relations with Russia. In Europe's Last Frontier? (pp. 55-77). Palgrave Macmillan, New York.

Spiegel. (2012). 'Better To Be a Dictator than Gay': Germany Slams Lukashenko Over Slur. Retrieved October 29, 2019, from https://www.spiegel.de/international/europe/better-to-be-a-dictator-thangay-germany-slams-lukashenko-over-slur-a-819458.htm .

UNHCR. (2014). Submission by the United Nations High Commissioner for Refugees. For the Office of the High Commissioner for Human Rights' Compilation Report -Universal Periodic Review. 
Europe's Last Dictatorship: The State of Civil Liberties in Belarus

Retrieved October 29, 2019 from https://www.uprinfo.org/sites/default/files/document/belarus/session_22_-

_mai_2015/unhcr_upr22_blr_e_main.pdf.

Viasna (2017). Report on Violations of Roma rights in Belarus Sent to UN. Retrieved October 27, 2019, from http://spring96.org/en/news/88247.

Zaçellari, M., Miço, H. and Sinitsa, I. (2018). Inclusive education for Roma children in Albania and Belarus (legal situation, accessibility, opportunities to learn in own language and support of ethnic identity). Polish Journal of Educational Studies, 71(1), pp. 195-211. 